\title{
Total Reflection X-Ray Fluorescence Spectroscopy
}

\author{
Tibo Yang, Xinyang Fan, Jinge Zhou \\ Chengdu University of Technology, Chengdu, China \\ Email:y13056633827@163.com
}

How to cite this paper: Yang, T.B., Fan, X.Y. and Zhou, J.G. (2020) Total Reflection X-Ray Fluorescence Spectroscopy. Open Access Library Journal, 7: e6671. https://doi.org/10.4236/oalib.1106671

Received: July 27, 2020

Accepted: August 22, 2020

Published: August 25, 2020

Copyright (C) 2020 by author(s) and Open Access Library Inc.

This work is licensed under the Creative Commons Attribution International License (CC BY 4.0).

http://creativecommons.org/licenses/by/4.0/

\section{(c) (i) Open Access}

\begin{abstract}
Total reflection X-ray fluorescence (TXRF) is widely used in trace elements, ultra-trace element, and multi-element analysis due to its low detection limit and low energy spectrum background count. This article studies the development and application of TXRF. The development of TXRF can be divided into three stages. The first stage: Total reflection was first presented in 1971 to the publication of the first monograph about TXRF in 1997, mainly the theoretical research of TXRF and the application in single element analysis; the second stage: 1998 to 2017, during this stage, TXRF has developed rapidly, from single element analysis to multi-element simultaneous analysis, mainly used in geology, environment, chemistry, medicine, etc. field; the third stage: based on the extensive application of TXRF, conduct in-depth research on its basic theory, further improve the performance of the instrument, and achieve more accurate analysis results.
\end{abstract}

\section{Subject Areas}

Nuclear Physics

\section{Keywords}

X-Ray Total Reflection, Critical Angle, Elemental Analysis

\section{Introduction}

Total-reflection X-ray fluorescence (TXRF) is a multi-element simultaneous analysis technology developed based on X-ray fluorescence (XRF) [1]. Different from the incidence angle of XRF, which is about $40^{\circ}$, the primary rays of TXRF are incident at an angle slightly less than the critical angle to illuminate a very small amount of samples on the optical platform (sample carrier) [2]. Due to the high reflectivity of the carrier, the rays are reflected. The primary rays are hardly 
recorded by the detector, which greatly reduces the background count in the energy spectrum and improves the detection efficiency. In the analysis of ultra-trace elements [3], due to the ultra-low background count, the characteristic peaks will not be covered by the background count, to achieve the purpose of trace element analysis. Figure 1 shows the spectrum of XRF and TXRF. In the figure, the background interference of XRF is much greater than that of TXRF. Therefore, TXRF has the following characteristics [4]:

1) High sensitivity;

2) Low detection limit;

3) No matrix effect;

4) The quantitative analysis by the internal standard method is simple;

5) The sample size is small (as low as ng to ug based on sample preparation);

6) Non-destructive testing;

7) Multielement simultaneous analysis.

\section{The Principle of TXRF}

$\mathrm{X}$-ray fluorescence analysis uses the interaction of primary X-rays with substances to generate characteristic X-rays and analyze the characteristic X-rays [3]. Figure 2 shows how characteristic $X$-rays are generated.

The energy state of electrons in atoms is quantized [5], and characteristic $\mathrm{X}$-rays generated by ionization or excitation correspond to specific atoms according to their energy. According to Moseley's law [6] and Sheman equation, the elements can be analyzed qualitatively and quantitatively. When total reflection occurs, the primary rays are emitted along the incident direction and can hardly be recorded by the detector, thus greatly reducing the background count. The wide incident wave and the wide reflected wave cause interference [3], forming a standing wave, which can generate in the thin samples on the sample stage and the total reflection surface of the sample stage. Figure 3 is the Schematic of total reflection and the generation of standing waves field.

At this time, the sample is excited by both incident radiation and total reflection

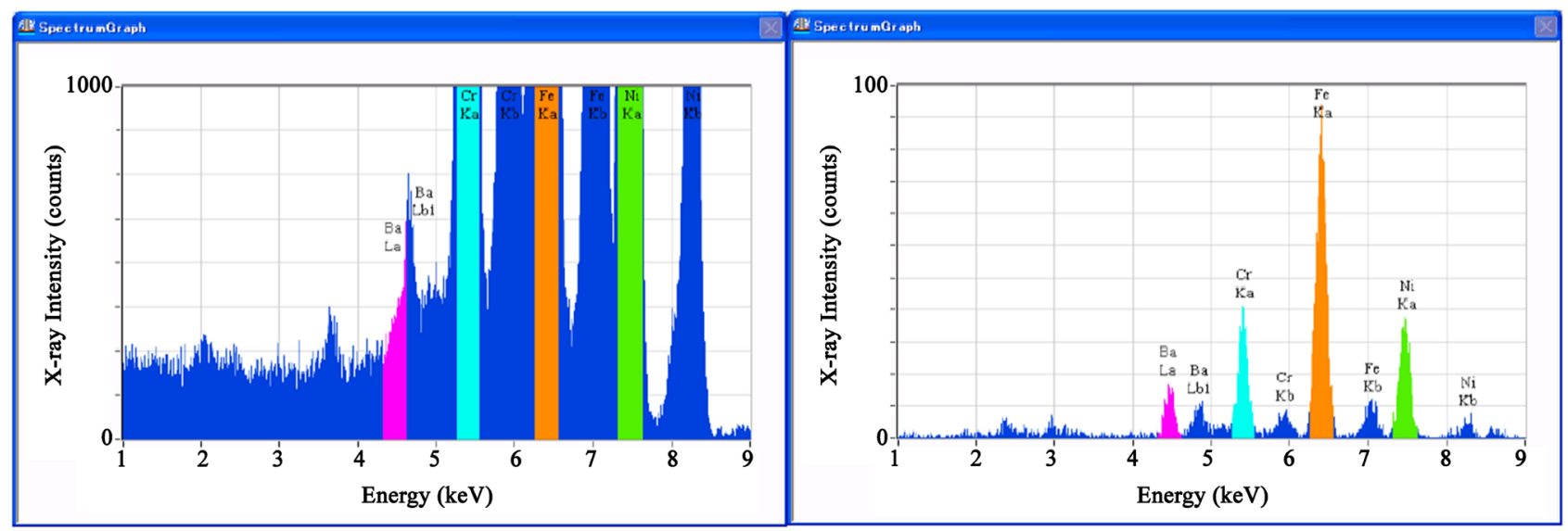

(a)

(b)

Figure 1. (a) XRF Spectra; (b) TXRF Spectrum [4]. 


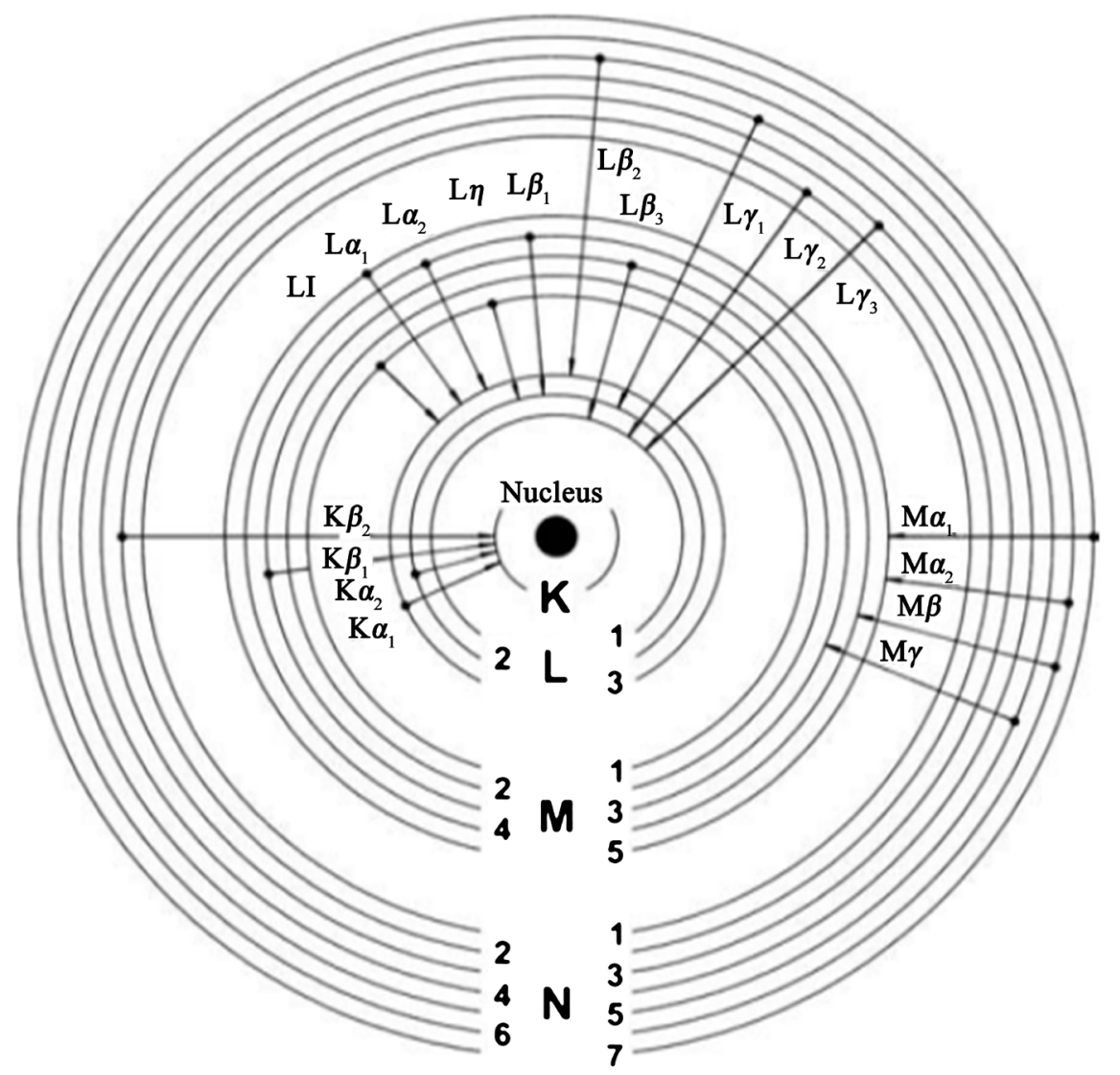

Figure 2. The generation of characteristic X-rays.

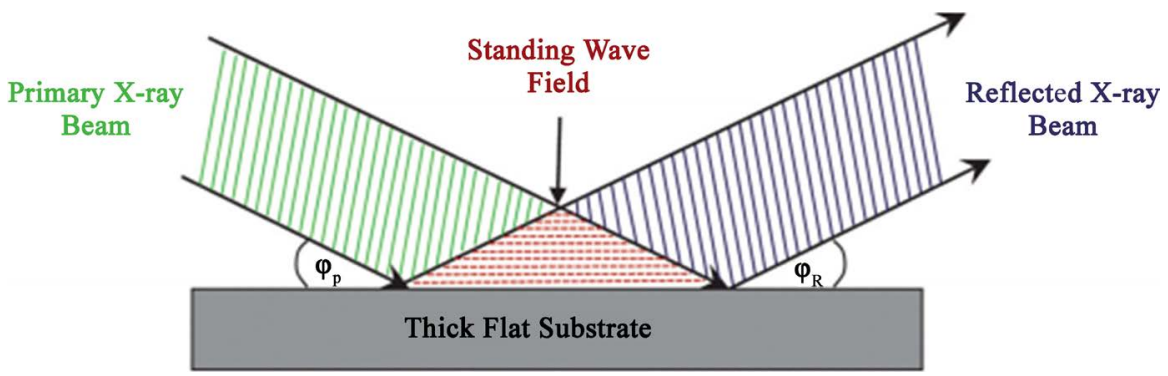

Figure 3. Schematic of total reflection and generation of standing waves field [7].

radiation, and its fluorescence intensity shows a sudden increase trend [2]. Figure 4 shows the geometric arrangement of XRF and TXRF.

The primary ray source is an X-ray tube, which irradiates the sample on the sample stage through a certain angle to generate secondary X-rays [9], and the secondary X-rays then recorded by the detector. When the resonance and quantum effects at the absorption limit are not considered [10], the critical angle is related to the reflector material and the wavelength of the incident ray. The critical angle [11] of X-ray total reflection is determined by Equation (1):

$$
\alpha_{\mathrm{c}} \approx \frac{1.65}{E} \sqrt{\frac{Z}{A} \times \rho}
$$

In Equation (1), $E$ is the energy of the primary ray; 

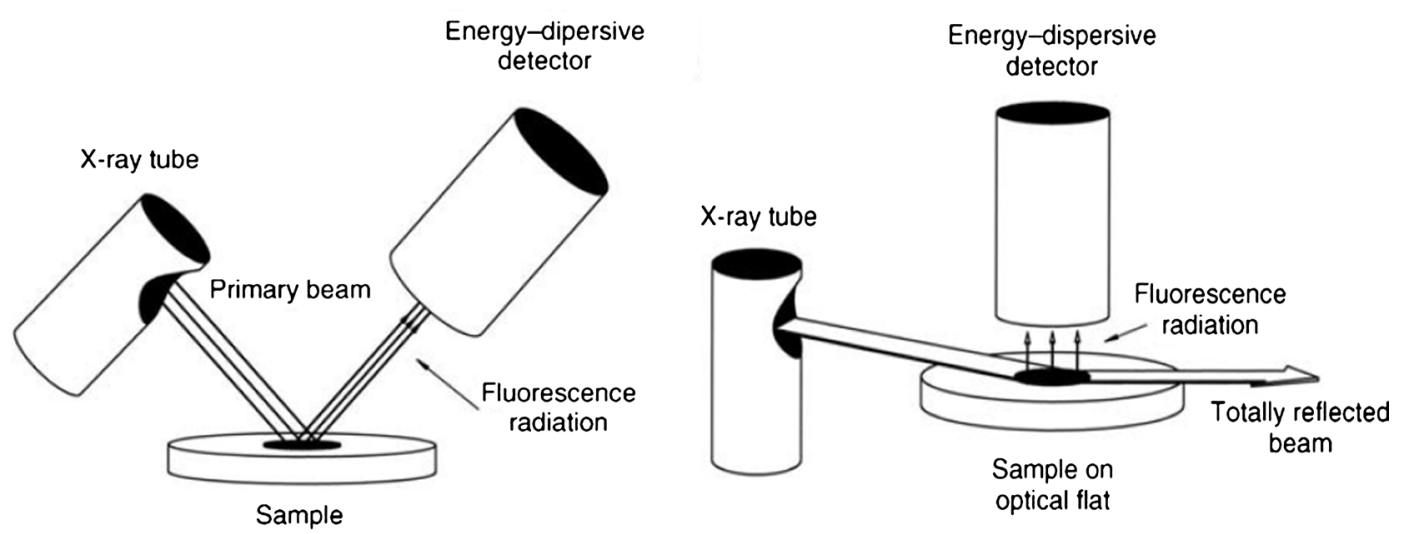

Figure 4. Geometric arrangement of XRF and TXRF [8].

$\alpha_{c}$ is the critical angle;

$A$ is the atomic weight of the sample stage;

$Z$ is the atomic number of the sample stage;

$\rho$ is the density of the sample stage.

The main differences between TXRF and XRF are the incident angle of the primary rays (XRF is generally about $40^{\circ}$, TXRF is generally less than $0.1^{\circ}$-critical angle [3] [12]); the smoothness of the sample stage, and the requirements of the sample (TXRF requires the reflectivity of the sample stage High to ensure the occurrence of total reflection, the sample thickness is generally less than $100 \mathrm{um}$ [4] [13]); the position of the detector (due to the total reflection, the detector can be placed very close to the sample to improve the detection efficiency of the detector, generally $0.5 \mathrm{~mm}[4])$.

\section{Development and Application of TXRF}

\subsection{Initial Development of TXRF}

Since 1971 Yoneda et al. [13] first application the total reflection technology to $\mathrm{XRF}$, they determined uranium in seawater, iron in the blood, and rare earth elements in hot-spring water. The theoretical basis and experimental conditions were subsequently investigated. In Vienna, Austria, Wobrauschek wrote a Ph.D. thesis on the subject [14], and together with Aiginger, they reported detection limits of nanograms [15] [16]. In Geesthacht near Hamburg, Germany, Knoth, and Schwenke found element traces on the ppb-level [17] [18]. In the decade after 1980, a great variety of applications promoted a growing interest, the number of instruments in use increased to about 200 worldwide.

In 1981, the West German Rich Seifer Company successfully developed the first commercial total reflection X-ray fluorescence spectrometer. Since then, the development and application of the TXRF instrument have been rapidly developed and improved. Since 1984, several TXRF seminars have been held internationally [19]. Since the 1990s, China has been led by the Institute of High Energy Physics [10], the Institute of Modern Physics [20], and the Chinese Academy of Atomic Energy, which have successively carried out the development of TXRF 
analysis devices and the research and promotion of analysis methods.

In 1983, the angular dependence of the fluorescence intensities in the range below the critical angle of total reflection was first observed by Becker et al. [21] It led to the nondestructive investigation of surface contamination and thin near-surface layers. In 1986, the X-radiation of a synchrotron was first used for excitation by Iida et al. [22]. At a first "workshop" in Geesthacht in 1986, the participants decided to call the new method "total reflection X-ray fluorescence analysis" and introduced the acronym "TXRF". In 1991, Wobrauschek, Aiginger, Schwenke, and Knoth won the distinguished Bunsen-Kirchhoff Prize of the DASp (Deutsche Arbeitskreis fur Angewandte Spektroskopie) for the development of TXRF. Table 1 shows several important stages of the initial development of the TXRF.

\subsection{TXRF Mid-Development Application}

In the years after first reviews and book contributions were published on the subject of TXRF (e.g. [24] [25]). The number of papers about TXRF grew explosively from some 3 to about 125 papers per year with large fluctuations [8]. TXRF is successfully applied all over the world. It is widely used in the analysis and determination of macro, trace elements in various fields such as chemical industry, food, environmental protection, biology, medicine, legal inspection, high-purity materials, geology and minerals, metallurgy, etc. [26]. In 1995, Tian Yuhong et al. [10] researched the structure of the secondary total reflection system. The minimum detection limit of the copper target under small beam conditions can reach $0.6 \times 10^{-9}$, and the platinum target can reach $2 \times 10^{-9}$. In 1996, when Christina Streli [27] used TXRF to analyze light elements, he compared the effects of possible $\mathrm{x}$-ray sources such as standard $\mathrm{x}$-ray tubes, special windowless $\mathrm{x}$-ray tubes, and synchrotron radiation, and he using special excitation sources and special spectral correction components to reduce the detection limit and reduce the background count. C. Surely, Burba P, et al. have further studied the $\mathrm{X}$-ray source, he found that detection limits depend upon the source. When

Table 1. TXRF several important stages of initial development.

\begin{tabular}{|c|c|c|}
\hline Time & Representatives & Main work \\
\hline 1971 & Yoneda Y, Horiuchi T & First proposed to apply total reflection technology to XRF \\
\hline 1978 & Knoth, J. and Schwenke, $\mathrm{H}$ & Found element traces on the ppb-level \\
\hline 1981 & Rich Seifer West Germany & $\begin{array}{l}\text { Successfully developed the first commercial total reflection } \\
\text { X-ray fluorescence spectrometer }\end{array}$ \\
\hline 1983 & Becker & $\begin{array}{l}\text { Studied the relationship between fluorescence intensity } \\
\text { and angle below the critical angle }\end{array}$ \\
\hline 1986 & Iida, A., Yoshinaga, A & Apply synchrotron radiation to TXRF \\
\hline 1991 & $\begin{array}{l}\text { Wobrauschek, Aiginger, } \\
\text { Schwenke, and Knoth }\end{array}$ & $\begin{array}{l}\text { Won the distinguished Bunsen-Kirchhoff Prize for the } \\
\text { development of TXRF }\end{array}$ \\
\hline 1997 & Klockenkamper [23] & Publication of the first monograph on TXRF \\
\hline
\end{tabular}


using synchrotron radiation as an X-ray source the detection limits are in the range of some hundred femtograms [28] while in the range of some pg when using a special windowless X-ray tube with a-Si anode [29].

TXRF is used everywhere. In terms of environmental protection, the TXRF analysis of environmental samples (such as water, soil, air particles, animals and plants, etc.) [30]-[37] can evaluate environmental changes. Erick K. Towett et al. [32] [33] used TXRF to study the element content in the soil, and compared with the ICP-MS measurement results after digestion, it showed the feasibility of TXRF measurement results in soil. Liu Guangya [34] used TXRF to measure atmospheric particles and evaluate air pollution. Through TXRF research on geological samples (such as ores, crystals, and mineral raw materials), geological and geochemical surveys and mineral census are realized. Cherkashina Ty et al. [38] used TXRF to study ore samples and proved that TXRF can quickly detect ore samples. In the chemical industry, product quality control can be achieved by analyzing the element or impurity content of chemical products (petroleum and petroleum products, fertilizers, wastes, films) [39] [40] [41] [42]. In foreign countries, I. De La Calle et al. [41] used TXRF to measure metal content in smelting slag to assess whether the smelting slag treatment process is appropriate and judge whether the slag can be recycled. F. M. Adebiyi et al. [39] used TXRF to analyze trace elements in Nigerian oil sands. In the field of medicine and food, Lankosz M W et al. [43] used TXRF to measure trace elements in human brain tissue to distinguish the disease level. Li Meng [44] studied the relationship between mineral elements and diseases through TXRF analysis of the hair of chronic hepatitis B patients and healthy people. In China, the use of TXRF is mainly concentrated in food (such as fish, fruits, nuts, pollen, tea) [45] [46] [47] [48] and the medical field, such as Yu Huichun et al. [45] for different types of wine grapes. Wang Shuxun [49] uses TXRF analysis Ganoderma lucid from different origins. Table 2 shows some applications of TXRF in mid-term development.

\subsection{The Development of TXRF in Recent Years}

In the past few years, many instrument improvements have been done, and elemental analysis has been done in the following applied research fields.

1) Minerals: feldspar, antimony oxide, gold ore, fluorite [50];

2) Metallurgy: nickel electrolyte, cast iron, bearings;

3) Environmental protection: pure water [51], mineral water, tap water, sewage, atmospheric dust, sludge, high salinity salt lake water; soil [52];

4) Chemical industry: catalyst formula for purifying automobile exhaust, sulfur in diesel, ceramic glaze formula;

5) Biology: teeth, marine animals, blood [53], cells and proteins, body fluids;

6) Legal inspection: Appraisal of samples at the crash site [54];

7) Material: glass, high purity quartz impurity content; medicine: trace elements in hair [46], nails, harmful trace elements in salvia; 
Table 2. TXRF Some mid-term development applications.

\begin{tabular}{|c|c|c|}
\hline Author & Related applications & Title of article \\
\hline $\begin{array}{l}\text { Erick K. } \\
\text { Towett }\end{array}$ & Elemental content in soil studied with TXRF & $\begin{array}{l}\text { Bromine and bromine content in soils: Analytical approach from total } \\
\text { reflection X-ray fluorescence spectrometry }\end{array}$ \\
\hline Liu Guangya & $\begin{array}{l}\text { Measuring atmospheric particles with TXRF to } \\
\text { assess air pollution }\end{array}$ & $\begin{array}{l}\text { Analysis of the Concentration of Harmful Elements of Atmospheric } \\
\text { Particulate Matter in Wuhan Based on Total Reflection X-Ray Fluorescence }\end{array}$ \\
\hline $\begin{array}{l}\text { Cherkashina } \\
\text { T Y }\end{array}$ & A TXRF study of ore samples was used & $\begin{array}{l}\text { Applicability of direct total reflection X-ray fluorescence spectrometry for } \\
\text { multielement analysis of geological and environmental objects }\end{array}$ \\
\hline I.De La Calle & $\begin{array}{l}\text { Measurement of metal content in smelting } \\
\text { slag using TXRF }\end{array}$ & $\begin{array}{l}\text { Determination of residual metal concentration in metallurgical slag after } \\
\text { acid extraction using total reflection X-ray fluorescence spectrometry }\end{array}$ \\
\hline F. M. Adebiyi & $\begin{array}{l}\text { Analysis of trace elements in Nigerian oil sands } \\
\text { using TXRF }\end{array}$ & Characterization of Nigerian Oil Sands by TXRF Spectrometry \\
\hline Li Meng & $\begin{array}{l}\text { Analysis of hair TXRF in patients with chronic } \\
\text { hepatitis B and healthy population }\end{array}$ & $\begin{array}{l}\text { Comparative analysis of the TXRF of } 16 \text { mineral elements in the hair of } \\
\text { patients with chronic hepatitis B }\end{array}$ \\
\hline Huichun & Different types of wine grapes & $\begin{array}{l}\text { Determination of } 16 \text { mineral elements in different varieties of wine grape by } \\
\text { TXRF method }\end{array}$ \\
\hline
\end{tabular}

8) Food: beneficial and harmful elements in beverages, rice [55], plant materials, leaf roots, and stems.

In 2017, Mercedes Radio [56] investigated the effect of an inorganic $\left(\mathrm{CaCl}_{2}\right)$ and an organic matrix on metals quantification by TXRF for liquid samples. In 2018, Tsugufumi Matsuyama [57] proposed a new methodology to evaluate uranium concentration in water containing many kinds of impurities by total reflection X-ray fluorescence analytical. Hikari Takahara [58] developed a non-dissolution preparation method for powder sample analysis by total reflection X-ray fluoresce spectrometry (TXRF). In 2019, I.Szaloki [12], et al. presented a new fundamental parameter model and calculation algorithm for quantitative analysis for total reflection X-ray fluorescence analytical technique. In 2020, Aleksandra Winkler [59] et al. determined the elemental composition of various herbal infusions and teas, including trace elements by using total reflection X-ray fluorescence (TXRF). Gruber Andreas [60] precisely quantify iron and other trace metals in a variety of biological samples by total reflection X-ray fluorescence (TXRF) analysis. Alex von Bohlen [7] explained that TXRF analysis is not working completely free of matrix effects if the thickness of the residue of matrix samples according to the results of TXRF analysis of the different components of beverages exceeds a certain margin. Table 3 is a number of applications TXRF in recent years.

\section{Summary and Outlook}

It has been 50 years since the first application of total reflection technology to XRF in 1971. During this period, TXRF has developed rapidly. Based on XRF, the background caused by scattering has been overcome, making it possible to analyze ultra-trace elements. It solves the measurement problem of multiple 
Table 3. TXRF some applications in recent years.

\begin{tabular}{|c|c|c|c|}
\hline Year & Author & Related applications & Title of article \\
\hline 2020 & $\begin{array}{l}\text { Aleksandra } \\
\text { Winkler }\end{array}$ & $\begin{array}{l}\text { The elemental composition of various herbal infusions and teas } \\
\text { was determined by full reflection X-ray fluorescence analysis } \\
\text { (TXRF) }\end{array}$ & $\begin{array}{l}\text { Total reflection X-ray fluorescence analysis of the } \\
\text { elemental composition of herbal infusions and teas }\end{array}$ \\
\hline 2020 & $\begin{array}{l}\text { Gruber } \\
\text { Andreas }\end{array}$ & $\begin{array}{l}\text { Determination of iron and other trace elements in various } \\
\text { biological samples by full reflection X-ray fluorescence analysis }\end{array}$ & $\begin{array}{l}\text { Total reflection X-ray fluorescence spectrometry for trace } \\
\text { determination of iron and some additional elements in } \\
\text { biological samples. }\end{array}$ \\
\hline 2020 & $\begin{array}{l}\text { Alex von } \\
\text { Bohlen }\end{array}$ & $\begin{array}{l}\text { TXRF analysis is not working completely free of matrix effects if } \\
\text { the thickness of the residue of samples exceeds a certain margin } \\
\text { according to the results of TXRF analysis of the different } \\
\text { components of beverages notes }\end{array}$ & $\begin{array}{l}\text { Experimental evidence of matrix effects in total reflection } \\
\text { X-ray fluorescence analysis: Coke case }\end{array}$ \\
\hline 2019 & I.Szaloki & $\begin{array}{l}\text { presented a new fundamental parameter model and calculation } \\
\text { algorithm for quantitative analysis for total reflection X-ray } \\
\text { fluorescence analytical technique }\end{array}$ & $\begin{array}{l}\text { Fundamental parameter model for quantification of total } \\
\text { reflection X-ray fluorescence analysis }\end{array}$ \\
\hline 2018 & $\begin{array}{l}\text { Tsugufumi } \\
\text { Matsuyama }\end{array}$ & $\begin{array}{l}\text { proposed a new methodology to evaluate uranium concentration } \\
\text { in water containing many kinds of impurities by total reflection } \\
\text { X-ray fluorescence analytical }\end{array}$ & $\begin{array}{l}\text { Determination of uranium in immersion liquid of } \\
\text { demolition waste using total reflection X-ray fluorescence } \\
\text { analysis }\end{array}$ \\
\hline 2018 & $\begin{array}{l}\text { Hikari } \\
\text { Takahara }\end{array}$ & $\begin{array}{l}\text { developed non-dissolution preparation method for powder sample } \\
\text { analysis by total reflection X-ray fluoresce spectrometry (TXRF) }\end{array}$ & $\begin{array}{l}\text { Method development for the analysis of poorly soluble } \\
\text { solids by total reflection X-ray fluorescence spectrometry }\end{array}$ \\
\hline 2017 & $\begin{array}{l}\text { Mercedes } \\
\text { Regadio }\end{array}$ & $\begin{array}{l}\text { investigated the effect of an inorganic }\left(\mathrm{CaCl}_{2}\right) \text { and an organic } \\
\text { matrix on metals quantification by TXRF for liquid samples. }\end{array}$ & $\begin{array}{l}\text { Direct Analysis of Metal Ions in Solutions with High Salt } \\
\text { Concentrations by Total Reflection X-ray Fluorescence }\end{array}$ \\
\hline
\end{tabular}

elements in geological samples that have plagued the scientific community for many years. Due to the very small amount ( $\mu \mathrm{L}$ or $\mu \mathrm{g}$ ), the matrix effect can be almost eliminated, making the analysis results more accurate. Total reflection $\mathrm{X}$-ray analysis technology can detect almost all elements in the periodic table (from (B) boron to $(\mathrm{U})$ uranium), and even superheavy elements in the actinide series.

Since the amount of sample is very small, it is easy to be contaminated during sample preparation and testing. Sample preparation is a key process in TXRF analysis and is particularly important for the study of sample preparation. With the continuous improvement of the TXRF spectrometer, the more economical, portable and easy-to-operate TXRF spectrometer will continue to be marketed.

\section{Acknowledgements}

Thanks to the help of classmates and teachers, we can complete the paper smoothly.

\section{Conflicts of Interest}

The authors declare no conflicts of interest regarding the publication of this paper.

\section{References}

[1] Streli, C., Aiginoer, H. and Wobrauschek, P. (1989) Total Reflection X-Ray Fluorescence Analysis of Low-Z Elements. Spectrochimica Acta Part B: Atomic Spectroscopy, 44, 491-497. https://doi.org/10.1016/0584-8547(89)80055-2 
[2] Li, N.Y. (2020) Study on a New Rapid Quantitative Method of Total Reflection X-Ray Fluorescence Spectrometry. Shanghai Normal University, Shanghai.

[3] Klockenkamper, R. and Von Bohlen, A. (2014) Total-Reflection X-Ray Fluorescence Analysis and Related Methods. John Wiley \& Sons, Hoboken. https://doi.org/10.1002/9781118985953

[4] Jin, A. (2017) An Accurate Measurement Method Based on Total Reflectance X-Ray Fluorescence Spectrometry. China University of Petroleum, Beijing.

[5] Lu, X.T. (2000) Atomic Physics. Atomic Energy Press, Beijing.

[6] Moseley, H.G.J. (1913) The Attainment of High Potentials by the Use of Radium. Proceedings of the Royal Society A, 88, 471-476. https://doi.org/10.1098/rspa.1913.0045

[7] Von Bohlen, A. and Fernandez-Ruiz, R. (2020) Experimental Evidence of Matrix Effects in Total Reflection X-Ray Fluorescence Analysis: Coke Case. Talanta, 209, Article ID: 120562. https://doi.org/10.1016/j.talanta.2019.120562

[8] Wang, X.H., Wang, Y.M. and Wang, Y.F. (2002) Total Reflection X-Ray Fluorescence Analysis. Atomic Energy Press, Beijing. https://doi.org/10.1080/14786440908637137

[9] Barkla, C.G. (1911) XXXIX. The Spectra of the Fluorescent Rontgen Radiations. The London, Edinburgh, and Dublin Philosophical Magazine and Journal of Science, 22, 396-412. https://doi.org/10.1080/14786440908637137

[10] Tian, Y.U., Tan, J.L., Zheng, S.H., et al. (1995) Study on Total Reflection X Fluorescence Analysis Technology. Nuclear Electronics and Detection Technology, 15, 7-11.

[11] Fan, Q.M. and Liu, Y.W. (1990) Nack-Grade Total Reflection X-Ray Fluorescence Analysis. Spectroscopy and Spectral Analysis, 10, 64-67.

[12] Szaloki, I., Racz, G. and Germany, A. (2019) Fundamental Parameter Model for Quantification of Total Reflection X-Ray Fluorescence Analysis. Spectrochimica Acta Part B: Atomic Spectroscopy, 156, 33-41. https://doi.org/10.1016/j.sab.2019.04.010

[13] Yoneda, Y. and Horiuchi, T. (1971) Optical Flats for Use in X-Ray Spectrochemical Microanalysis. Review of Scientific Instruments, 42, 1069-1070. https://doi.org/10.1063/1.1685282

[14] Wobrauschek, P. (1975) Totalreflexions-Rontgenfluoreszenzanalyse. PhD Thesis, Atominstitut der Osterreichischen Universitaten, Technical University of Vienna, Vienna.

[15] Aiginger, H. and Wobrauschek, P. (1974) A Method for Quantitative X-Ray Fluorescence Analysis in the Nanogram Region. Nuclear Instruments and Methods, 114, 157-158. https://doi.org/10.1016/0029-554X(74)90352-8

[16] Aiginger, H. and Wobrauschek, P. (1975) Total-Reflection X-Ray Fluorescence Spectrometric Determination of Elements in Nanogram Amounts. Analytical Chemistry, 47, 852-855. https://doi.org/10.1021/ac60356a034

[17] Knoth, J. and Schwenke, H. (1978) An X-Ray Fluorescence Spectrometer with Totally Reflection Sample Support for Trace Analysis at the PPB Level. Fresenius Zeitschrift für analytische Chemie, 291, 200-204. https://doi.org/10.1007/BF00480689

[18] Schwenke, H. and Knoth, J. (1982) A Highly Sensitive Energy-Dispersive X-Ray Spectrometer with Multiple Total Reflections of the Exciting Beam. Nuclear Instruments and Methods in Physics Research, 193, 239-243. 
https://doi.org/10.1016/0029-554X(82)90703-0

[19] Aiginger, H. (1991) Historical Development and Principles of Total Reflection X-Ray Fluorescence Analysis (TXRF). Spectrochimica Acta Part B: Atomic Spectroscopy, 46, 1313-1321. https://doi.org/10.1016/0584-8547(91)80180-B

[20] Tian Y.C., Zheng S.H. and Wang, Z.G. (1992) The Establishment of Total Reflection X Fluorescence Analysis Technique. Nuclear Electronics and Detection Technology, 12,86 .

[21] Becker, R.S., Golovchenko, J.A. and Patel, J.R. (1983) X-Ray Evanescent-Wave Absorption and Emission. Physical Review Letters, 50, 153-156. https://doi.org/10.1103/PhysRevLett.50.153

[22] Iida, A., Yoshinaga, A., Sakurai, K. and Gohshi, Y. (1986) Synchrotron Radiation Excited X-Ray Fluorescence Analysis Using Total Reflection of X-Rays. Analytical Chemistry, 58, 394-397. https://doi.org/10.1021/ac00293a029

[23] Klockenkamper, R. (1997) Total Reflection X-Ray Fluorescence Analysis. John Wiley \& Sons, Inc., New York.

[24] Klockenkamper, R., Knoth, J., Prange, A. and Schwenke, H. (1992) Total-Reflection X-Ray Fluorescence Spectroscopy. Analytical Chemistry, 64, 1115A-1123A. https://doi.org/10.1021/ac00047a717

[25] Klockenkamper, R. (1991) Totalreflexions-Röntgenfluoreszenzanalyse. In: Gunzler, H., et al., Eds., Analytiker-Taschenbuch, Springer, Berlin, 111-152. https://doi.org/10.1007/978-3-642-76028-0_5

[26] Wobrauschek, P. (2010) Total Reflection X-Ray Fluorescence Analysis-A Review. $X$-Ray Spectrometry, 36, 289-300. https://doi.org/10.1002/xrs.985

[27] Streli, C. (1997) Total Reflection X-Ray Fluorescence Analysis of Light Elements. Spectrochimica Acta Part B: Atomic Spectroscopy, 52, 52281-293.

[28] Streli, C., Bauer, V. and Wobrauschek, P. (1997) Recent Developments in TXRF of Light Elements. Advances in X-Ray Analysis, 39, 771-779.

https://doi.org/10.1007/978-1-4615-5377-9_86

[29] Burba, P., Willmer, P.G., Becker, M., et al. (1989) Determination of Trace Elements in High-Purity Aluminum by Total Reflection X-Ray Fluorescence after their Separation on Cellulose Loaded with Hexamethy Lenedithiocar Bamates. Spectrochimica Acta Part B: Atomic Spectroscopy, 44, 525-532. https://doi.org/10.1016/0584-8547(89)80060-6

[30] Zheng, X.Q. and Zhang, X.G. (2015) Research on the Method of Distinguishing Pyroclastic Rocks in Songliao Basin Using Total Reflection X-Ray Fluorescence Analysis Technology. Inner Mongolia Petrochemical Industry, 41, 74-76.

[31] Wang, L.L., Yuh, S., Li, L., et al. (2016) The Development of the TXRF Method and Its Application on the Study of Trace Elements in the Water at SSRF. Nuclear Instruments and Methods in Physics Research Section B: Beam Interactions with Materials and Atoms, 375, 49-55. https://doi.org/10.1016/j.nimb.2016.03.046

[32] Gallardo, H., Queralt, I., Tapias, J., et al. (2016) Bromine and Bromide Content in Soils: Analytical Approach from Total Reflection X-Ray Fluorescence Spectrometry. Chemosphere, 56, 294-301. https://doi.org/10.1016/j.chemosphere.2016.04.136

[33] Towette, K., Shepherd, D. and Cadisch, G. (2013) Quantification of Total Element Concentrations in Soils Using Total X-Ray Fluorescence Spectroscopy (TXRF). Science of the Total Environment, 463-464, 374-388. https://doi.org/10.1016/j.scitotenv.2013.05.068

[34] Liu, G.Y. (2014) The Analysis of Harmful Element Concentration of Atmospheric 
Particulate Matter in Wuhan Based on Total Reflection X-Ray Fluorescence Technology. University of South China, Hengyang.

[35] Yu, J.F. (2014) Enrichment and Acute Toxicity Analysis of Copepods in Yangshan Port. Shanghai Ocean University, Shanghai.

[36] Bilo, F., Lodolo, M., Borgese, L., et al. (2015) Evaluation of Heavy Metals Contamination from Environment to Food Matrix by TXRF: The Case of Rice and Rice Husk. Journal of Chemistry, 26, 375-379. https://doi.org/10.1155/2015/274340

[37] Bilo, F., Borgese, L., Dalipi, R., et al. (2017) Elemental Analysis of Tree Leaves by Total Reflection X-Ray Fluorescence: New Approaches for Air Quality Monitoring. Chemosphere, 178, 504-512. https://doi.org/10.1016/j.chemosphere.2017.03.090

[38] Cherkashinat, Y., Panteevas, V. and Pashkovag, V. (2014) Applicability of Direct Total Reflection X-Ray Fluorescence Spectrometry for Multielement Analysis of Geological and Environmental Objects. Spectrochimica Acta Part B: Atomic Spectroscopy, 99, 59-66. https://doi.org/10.1016/j.sab.2014.05.013

[39] Adebiyi, F.M., Asubiojo, O.I. and Ajayi, T.R. (2008) Characterization of Nigerian Oil Sands by TXRF Spectrometry. Petroleum Science \& Technology, 26, 29-39. https://doi.org/10.1080/10916460600705618

[40] Resendel, V. and Nascentesc, C.A. (2016) Simple Method for the Multi-Elemental Analysis of Organic Fertilizer by Slurry Sampling and Total Reflection X-R Ay Fluorescence. Talanta, 147, 485-492. https://doi.org/10.1016/j.talanta.2015.10.007

[41] Delc, I., Quade, M., Krugmann, T., et al. (2014) Determination of Residual Metal Concentration in Metallurgical Slag After Acid Extraction Using Total Reflection X-Ray Fluorescence Spectrometry. X-Ray Spectrometry, 43, 345-352. https://doi.org/10.1002/xrs.2561

[42] Romero, V., Costas-Mora, I., La Villa, I., et al. (2016) Headspacethin-Film Microextraction onto Graphene Membranes for Specific Detection of $\mathrm{Me}$ thyl(Cyclopentadienyl)-Tricarbonyl Manganese in Water Samples by Total Reflection X-Ray Fluorescence. Spectrochimica Acta Part B: Atomic Spectroscopy, 126, 65-70. https://doi.org/10.1016/j.sab.2016.10.011

[43] Lankosz, M.W, Grzelak, M., Ostachowicz, B., et al. (2014) Application of the Total Reflection X-Ray Fluorescence Method to the Elemental Analysis of Brain Tumors of Different Types a Grade of Malignancy. Spectrochimica Acta Part B: Atomic Spectroscopy, 101, 98-105. https://doi.org/10.1016/j.sab.2014.07.019

[44] Li, M. (2013) TXRF Comparative Analysis of 16 Mineral Elements in the Hair of Patients with Chronic Hepatitis B. Chinese Journal of Health Inspection, No. 8, 1915-1917.

[45] Yu, H.C., Chen, W. and Wu, X.R. (2013) Study on the Determination of 16 Mineral Elements in Different Grape Varieties by TXRF Method. Wine Making Technology, No. 8, 103-105.

[46] Li, M. (2013) Determination of 16 Mineral Elements in Walnut with Constant Pressure Digestion-TXRF. Modern Food Science and Technology, 29, 1170-1172.

[47] Chen, W., Han, X.F., Liu, W.W., et al. (2012) TXRF Determination of 9 Life Elements in Pine Pollen. Journal of Analytical Testing, 31, 1009-1012.

[48] Xie, M.Y., Cao, C.Y., Wen, H.L., et al. (2000) Elemental and Elemental Binding Analysis of Selenium Tea in Enshi Area. Journal of Nutrition, 22, 278-281.

[49] Wang, S.X. (2014) TXRF Determination of 16 Mineral Elements in Ganoderma Lucid from Different Origin. Jiangxi Science, 32, 503-505.

[50] Alov, N. and Sharanov, P. (2018) Elemental Analysis of Copper-Zinc Ores by Total 
Reflection X-Ray Fluorescence Using Nonaqueous Suspensions. Analytical Letters, 51, 1789-1795. https://doi.org/10.1080/00032719.2017.1390758

[51] Espinoza-Quinones, F.R., Palacio, S.M., Modenes, A.N., et al. (2010) Water Quality Assessment of Toledo River and Determination of Metal Concentrations by Using SR-TXRF Technique. Journal of Radioanalytical and Nuclear Chemistry, 283, 465-470. https://doi.org/10.1007/s10967-009-0438-3

[52] Towett, E.K., Shepherd, K.D. and Cadisch, G. (2013) Quantification of Total Element Concentrations in Soils Using Total X-Ray Fluorescence Spectroscopy (TXRF) Science of the Total Environment, 463, 374-388. https://doi.org/10.1016/j.scitotenv.2013.05.068

[53] Mota, C.L., Pickler, A., Braz, D., et al. (2018) SR-TXRF Analysis of Trace Elements in Whole Blood and Heart of Rats: Effects of Irradiation with Low and High Doses. Journal of Instrumentation, 13, C04021. https://doi.org/10.1088/1748-0221/13/04/C04021

[54] Sarapura, P., Gonzalez, M.F, Gonzalez, F., et al. (2019) Application of Total X-Ray Fluorescence to Gunshot Residue Determination. Applied Radiation and Isotopes, 153, Article ID: 108841. https://doi.org/10.1016/j.apradiso.2019.108841

[55] Fabjola, B., Marco, L., Laura, B., et al. (2015) Evaluation of Heavy Metals Contamination from Environment to Food Matrix by TXRF: The Case of Rice and Rice Husk. Journal of Chemistry, 2015, Article ID: 274340. https://doi.org/10.1155/2015/274340

[56] Mercedes, R., Sofia, R., Koen, B. and Tom, V.H. (2017) Direct Analysis of Metal Ions in Solutions with High Salt Concentrations by Total Reflection X-Ray Fluorescence. Analytical Chemistry, 89, 4595-4603. https://doi.org/10.1021/acs.analchem.7b00097

[57] Matsuyama, T., Izumoto, Y., Ishii, K., Sakai, Y. and Yoshii, H. (2018) Determination of Uranium in Immersion Liquid of Demolition Waste Using Total Reflection X-Ray Fluorescence Analysis. Spectrochimica Acta Part B: Atomic Spectroscopy, 149, 35-41. https://doi.org/10.1016/j.sab.2018.07.010

[58] Takahara, H., Ohbuchi, A. and Murai, K. (2018) Method Development for the Analysis of Poorly Soluble Solids by Total Reflection X-Ray Fluorescence Spectrometry. Spectrochimica Acta Part B: Atomic Spectroscopy, 149, 276-28. https://doi.org/10.1016/j.sab.2018.07.008

[59] Winkler, A., Rauwolf, M., Sterba, J.H., et al. (2020) Total Reflection X-Ray Fluorescence Analysis of the Elemental Composition of Herbal infusions and Teas. Journal of the Science of Food and Agriculture, 100, 4226-4236. https://doi.org/10.1002/jsfa.10463

[60] Andreas, G., Riccarda, M., Alessa, W., et al. (2020) Total Reflection X-Ray Fluorescence Spectrometry for Trace Determination of Iron and Some Additional Elements in Biological Samples. Analytical and Bioanalytical Chemistry. 